\title{
Circular Initiatives for Industrial Sustainability
}

\author{
${ }^{1}$ Sudharto P. Hadi, ${ }^{2}$ Bulan Prabawani, ${ }^{1}$ Anis Qomariah \\ ${ }^{1}$ Graduate Program of Environmental Studies, ${ }^{2}$ Department of Business Administration, Faculty of \\ Social and Political Sciences, Universitas Diponegoro, Jl. Prof. Soedarto, SH Tembalang, Kota \\ Semarang, Jawa Tengah, Indonesia
}

\begin{abstract}
The industrial sector has been treated as the engine of economic growth contributing to GDP, job opportunities and business creation. However industrial activities also cause various environmental problems such as water, air pollution, also hazardous and non-hazardous waste generation. One approach to deal with this problem is by involving industries at Proper (business performance rating on environmental management). The industries that proactively managing its environmental impacts and resulting energy efficiency, reduce of water consumption and emission, reduce of hazardous and non-hazardous waste, improve bio-diversity, are awarded as green ranking. The gold ranking is awarded for industries which are able to create self-reliance communities through corporate social responsibility (CSR). To optimize environmental performance, the industries achieving beyond compliance level are obliged to adopt life cycle assessment (LCA).
\end{abstract}

\section{Introduction}

Environment and economics are considered by industries as a dichotomy. If they manage the environment, they are afraid of becoming uncompetitive because they have to allocate a sum of money for doing that. The Environment is then considered a cost center. If they pursue solely for profit they have to sacrifice the environment. Most industries manage the environmental impacts caused by their activities reactively, at the end of the pipe, when the pollution came up. This approach is costly because they have to build a waste installation unit. This approach is called linear economics in which industries take, use, and dispose of resources (such as energy, water, mineral materials). However, some industries participated at Proper categorized as beyond compliance that manages the environment proactively from the beginning of the pipe to the end of the pipe: from raw material, production, distribution, use, and waste. This approach is called circular economics. This paper observes three industries classified as beyond compliance practicing circular economics, the advantages obtained, and the prospects of implementing this approach. 


\section{Literature Review}

As quoted from Business News (2020), sustainability has emerged in the sector of manufacturing and industrial businesses. It pursues profit while minimizing negative environmental impacts by conserving energy and natural resources. The efforts to achieve sustainable industries consist of the use of recyclable and sustainable materials, reducing environmental impacts, sustainable packaging, eco-conscious shipping, practices basic recycling. The industries synergize between profit, people, and planet are categorized as fulfilling business ethics that business ethics include ecological ethics [14].

The circular economy is a concept of economic growth as an alternative to conventional manufacturing that emphasizes the integration of resources and production factors that are oriented towards efficiency, with the principles of reducing, reusing, and recycling to achieve value optimization and zero waste [3]. The circular economy is not a new concept, but it is an adaptation of cleaner production, energy conservation, and waste management [11]. It is a closed-loop economy in which the resources used are expected to provide added value in each stage of life or it is called from cradle to grave [13].

The implementation of a circular economy has become a concern in various industries i.e. fashion and textile which is considered as the most resource-intensive industry [1-2], mining [14], electronic as the industry with the highest waste growth [12], leather [4], and seafood industries [3]. Several forms of circular economy implementation are circular supply chain, recycling, and recovery, product life extension, sharing economy, and product-service systems [12],

The circular economy can be adapted at industrial, regional, and national levels [11], that The European Commission has made the circular economy an action plan [3]. The circular economy can be adapted easier technically because it is tangible. The methods to assess the $\mathrm{CE}$ are; a. material flow analysis, material energy flow analysis, and substance flow analysis Life, b. life cycle assessment, c. energy, emergy, exergy analysis, d. ecological footprint, e. physical input-output analysis, and $\mathrm{f}$. monetization of costs and benefits. However, the circular economy is difficult to measure from the socio-economic dimension [3].

\section{Methods}

This is a literature study that mainly uses secondary data. The data collected from Proper Secretariat are companies' reports on Proper activities and yearly Proper books published by the Indonesian Ministry of Environment and Forestry 2015 to 2020. In addition, this also employed interviews with relevant persons both at Proper secretariat and industries participating at Proper, as well as exposure to data of the industries in the Proper assessment process. Data analysis was performed with energy, emergy, exergy analysis, and cost monetization [3] using time-series data comparison.

\section{Results and Discussions}

Based on data released by Proper Secretariat [10], the number of participating industries at Proper in 2020 was 2038 in which 32 industries (1,5 percent) categorized as gold rank, 125 industries (6,13 percent) green, 1629 industries (79,93 percent) blue, 233 industries (11,43 percent) red and 2 industries ( 0,10 percent) black, and 16 industries are not 
operated (closed). This shows that most industries (79,93 percent) were at blue rank classifying as compliance industries meaning that they managed the environment business, as usual, with linier economics. Industries classified as beyond compliance (green and gold ranks) manage the environment proactively from raw material, process, and waste using $3 \mathrm{R}$ principles (reduce, reuse and recycle), adopt environmental management system (EMS) and Life Cycle Assessment (LCA) resulting from energy efficiency, reduction of water consumption, emission and waste generation, biodiversity improvement. In addition, they also practice community development through CSR. The following figure shows the life cycle assessment (LCA).

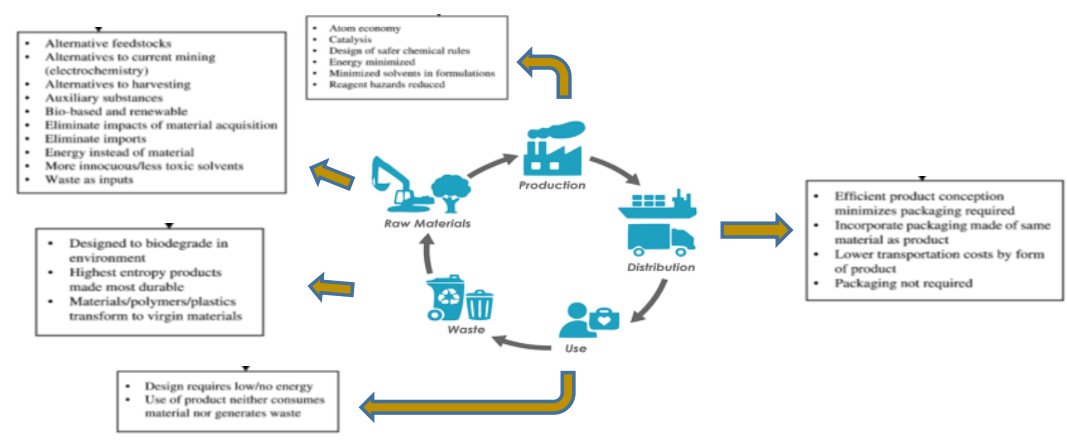

Fig. 1 LIFE CYCLE ASSESSMENT (LCA).

Most industries manage their environmental impacts caused by their activities focus solely on the production phase dealing with air and water pollutions and hazardous and non-hazardous waste. LCA encourages industries to manage raw materials, production, distribution, use, and waste. The description at every box the above figure shows the actions that can be taken by industries to reduce the energy, the consumption of water used and the reduction of emission and the waste generation in achieving effectiveness and efficiency.

The following table shows the environmental performance contributed by beyond compliance industries at Proper

Table 1. Profer's Achievement [5-10].

\begin{tabular}{|c|c|c|c|c|c|c|c|}
\hline \multirow{2}{*}{$\begin{array}{l}\text { Environmental } \\
\text { Improvement } \\
\text { Performance }\end{array}$} & \multicolumn{6}{|l|}{ Volume } & \multirow[t]{2}{*}{ Unit } \\
\hline & 2015 & 2016 & 2017 & 2018 & 2019 & 2020 & \\
\hline Energy Efficiency & 919.098 .110 & 249.808 .268 & 230.619 .485 & 273.613 .028 & 663.903 .297 & 430.244 .918 & GJ \\
\hline $\begin{array}{l}\text { Emission Reduction of } \\
\text { GHG }\end{array}$ & 48.076 .583 & 75.663 .410 & 33.626 .184 & 38.021 .962 & 93.828 .026 & 131.238 .206 & Ton \\
\hline $\begin{array}{l}\text { Conventional Emission } \\
\text { Reduction }\end{array}$ & - & - & 135.159 .368 & 18.689 .150 & 1.911 .617 & 5.942 .514 & Ton \\
\hline 3R Hazardous Waste & 4.786 .034 & 6.444 .846 & 13.610 .719 & 16.344 .704 & 17.756 .918 & 16.403 .947 & Ton \\
\hline $\begin{array}{l}\text { 3R Non-Hazardous } \\
\text { Waste }\end{array}$ & 9.419 .229 & 3.245 .604 & 11.557 .439 & 6.829 .428 & 9.925 .613 & 5.029 .181 & Ton \\
\hline $\begin{array}{l}\text { Water Consumption } \\
\text { Efficiency }\end{array}$ & 533.128 .233 & 447.463 .288 & 492.087 .329 & 540.448 .997 & 459.899 .904 & 339.529 .963 & M3 \\
\hline $\begin{array}{ll}\text { Waste } & \text { Generation } \\
\text { Reduction } & \end{array}$ & - & - & 535.490 .039 & 31.719 .609 & 50.598 .378 & 46.160 .473 & Ton \\
\hline
\end{tabular}


Efforts taken by industries in creating efficiency in utilizing resources and waste are significant from year to year. From 2015 to 2020, there has been a reduction in energy use, conventional emissions, 3R non-hazardous waste, water consumption, and waste generation, although with a decreasing trend. However, this reveals that environmental performance is increasing from year to year. A significant reduction and still showing an increasing trend of environmental performance is in the reduction of GHG emissions and $3 \mathrm{R}$ of hazardous waste.

In a business context that has an orientation towards profit, the efficiency and waste reduction above need to be monetized. The following shows the Proper achievement converted in Indonesian currency.

Table 2. Profer Achievement in Rupiah (Indonesia Currency) [5-10].

\begin{tabular}{|c|c|c|c|c|}
\hline \multirow[t]{2}{*}{ Aspect } & \multicolumn{4}{|l|}{ Saving (Rupiah) } \\
\hline & 2017 & 2018 & 2019 & 2020 \\
\hline $\begin{array}{l}\text { Energy } \\
\text { Efficiency }\end{array}$ & 32.595 .170 .533 .185 & 99.306 .924 .914 .953 & 103.879 .484 .094 .463 & 37.471 .930 .529 .125 \\
\hline $\begin{array}{l}\text { Emission } \\
\text { Reduction of } \\
\text { GHG }\end{array}$ & 10.786 .689 .145 .842 & 64.359 .454 .442 .400 & 25.661 .662 .696 .508 & 35.785 .112 .917 .651 \\
\hline $\begin{array}{l}\text { Conventional } \\
\text { Emission } \\
\text { Reduction }\end{array}$ & & 5.344 .928 .216 .796 & 690.616 .717 .074 & 10.228 .934 .925 .961 \\
\hline $\begin{array}{l}\text { 3R Hazardous } \\
\text { Waste }\end{array}$ & 893.478 .476 .838 & 10.105 .690 .712 .417 & 15.999 .736 .768 .060 & 10.671 .334 .064 .503 \\
\hline $\begin{array}{l}\text { 3R Non- } \\
\text { Hazardous } \\
\text { Waste }\end{array}$ & 852.050 .805 .207 & 3.904 .009 .328 .389 & 3.971 .416 .606 .661 & 3.285 .305 .681 .685 \\
\hline $\begin{array}{l}\text { Water } \\
\text { Consumption } \\
\text { Efficiency }\end{array}$ & 1.882 .253 .538 .212 & 63.300 .865 .723 .156 & 35.378 .259 .687 .111 & 3.678 .935 .451 .043 \\
\hline $\begin{array}{l}\text { Waste } \\
\text { Generation } \\
\text { Reduction }\end{array}$ & 6.067 .189 .368 .649 & 41.012 .225 .770 .851 & 7.045 .689 .2445 .467 & 6.013 .403 .286 .684 \\
\hline
\end{tabular}

The total saving achieved in 2020 reached Rp107 Trillion in utilizing resources of water, energy, non-hazardous waste and hazardous waste and reduction of water pollution and emission burden. The following description is the efforts taken by three industries categorized as beyond compliance in practicing part of LCA.

PT Sido Muncul made return condensate and optimized system resulting energy efficiency of $1.719 \mathrm{GJ}$, replacement of fossil energy with herbal waste-reducing emission $52,801,58$ ton. In addition, the company also utilized sludge for fertilizer resulting in hazardous waste and non-hazardous waste reduction of 555,84 tons.

Some programs of PT PJB (Jawa Bali Electric Generation) Unit of Muara Karang consisted of replacement of block valve bottom drain boiler creating water efficiency at 19.356,62 m3, modification of combustion chamber and turbine temperature resulting emission reduction of 7.458.260, ton $\operatorname{co} 2$ and implementation of $3 \mathrm{R}$ by purifying lube oil reducing non-hazardous waste generation 172,38 tons.

The circular initiatives of PT PKT (fertilizer factory) in Bontang, East Kalimantan were related to energy efficiency that was consisted of addition NG condensate for 
primary fuel reformer at factory $1 \mathrm{~A}$, optimization of secondary fuel purifier at ammonia factory 5, optimization of the use of low pressure at ammonia factory 2 , and utilization of fuel gas from unit hydrogen recovery unit for factory ammonia 4 . The energy efficiency achieved 369.796 GJ. The efforts for water efficiency include reduction of makeup water process NPK fusion using an application without impeller, Seal, Motor and Diaphragm, reuse condensate steam and process, utilization water backwash filter at the water treatment plant, recycle ammoniac with wastewater treatment unit. The reduction of water consumption achieved was 193,84 tons. The reduction of hazardous waste generation reached 39.193 tons gained from the following practices. Lubricant seal maze with deflector to prevent leak of lubricating oi at glide bearings steam turbine, replacement of chemical material packaging 250 liters with reuse packaging, installation oil mist fan at load gear gas turbine generator, reduction of a used catalyst with the decoking process and catalyst screening, utilization ash coal for paving block and concrete brick. To reduce non-hazardous waste generation, the efforts taken include adoption evaluation application system GCG, distribution planning and control system, online system: SAP application, employee self-service, the information system of filing dynamic, the information system of risk management, electronic integrity pact, replacement of packaging size, utilization of reject fertilizer. This can reduce non-hazardous waste generation by 2.217 tons. The reduction of air pollution reached 604.947. CO2 by reducing emission particulate utilizing pump without impeller, Seal, Motor and Diaphragm (NO ISEMOD) NPK scrubber, reuse $\mathrm{CO} 2$ excess at POPKA factory and bubbling $\mathrm{CO} 2$ at the emergency pond, replacement of seal with reverse Osmosis at factory 1 and 5.

The implementation of a circular economy carried out by the industries in the form of a circular supply chain as PT Sido Muncul has been done by the replacement of energy and material resources, recycling, and recovery as carried out by PT PJB through modification of combustion chamber and turbine. In addition, there are product life extensions as implemented by PT PKT through resource optimization.

This research has proven that the circular economy can significantly boost operational efficiency both at the company level and collectively on a regional and national scale. Hence, the government needs to set an action plan so that there are policies created to encourage a circular economy, even though this policy is non-binding. An alternative effort that can be used to drive the implementation of circular economy is through media and consumer pressures [12] that industries have an interest in maintaining their reputation, while there is higher consumer awareness of social issues.

The efforts made by the industries in a circular economy are categorized as reactive action, while in the context of an ideal circular economy, industries should have an operating design since the operation planning stage so that it involves a process from the selection of production inputs to zero waste efforts by valuing each process measurable. In addition, the circular economy assessment in the industry is relatively the same as the phenomena in other countries that have not involved an assessment of the socio-economic aspects.

\section{Conclusion and recommendations}

By adopting circular initiatives, managing the environmental impacts from the beginning of the pipe until the end of the pipe create benefit to industries themselves in the form of energy efficiency, reduction of water consumption, emission, and hazardous and non- 
hazardous waste generation. This will ensure industrial sustainability because the industries gain benefits from implementing LCA. The prospect of adopting LCA is better because the Ministerial Decree no 1 on Proper as a revision of previous regulation obligates beyond compliance industries to adopt LCA. The comprehensive practice of LCA at all stages of the production line is required for having more efficient and effective..

\section{References}

[1] Brydges, T. (2021). Closing the loop on take, make, waste: Investigating circular economy practices in the Swedish fashion industry. Journal of Cleaner Production, 293, 126245. https://doi.org/10.1016/j.jclepro.2021.126245

[2] Christensen, T. B. (2021). Towards a circular economy in cities: Exploring local modes of governance in the transition towards a circular economy in construction and textile recycling. Journal of Cleaner Production, 305, 127058. https://doi.org/10.1016/j.jclepro.2021.127058

[3] Jacob, C., Noirot, C., Anglada, C., \& Binet, T. (2021). The benefits of integrating socio-economic dimensions of circular economy practices in the seafood sector. Current Opinion in Environmental Science \& Health, 22, 100255. https://doi.org/10.1016/j.coesh.2021.100255

[4] Karuppiah, K., Sankaranarayanan, B., Ali, S. M., Jabbour, C. J. C., \& Bhalaji, R. K. A. (2021). Inhibitors to circular economy practices in the leather industry using an integrated approach: Implications for sustainable development goals in emerging economies. Sustainable Production and Consumption, 27, 1554-1568. https://doi.org/10.1016/j.spc.2021.03.015

[5] Kementerian Lingkungan Hidup dan Kehutanan. (2015). Proper.

[6] Kementerian Lingkungan Hidup dan Kehutanan. (2016). Proper.

[7] Kementerian Lingkungan Hidup dan Kehutanan. (2017). Creating Value Kolaborasi Pemerintah, Dunia Usaha, dan Masyarakat. In Proper.

[8] Kementerian Lingkungan Hidup dan Kehutanan. (2018). Kolaborasi Proper dan Dunia usaha untuk SDGs.

[9] Kementerian Lingkungan Hidup dan Kehutanan. (2019). Proper 4.0 as Simpel as it is.

[10] Kementerian Lingkungan Hidup dan Kehutanan. (2020). Masa Pandemi Masa untuk Peduli \& Berbagi.

[11] Li, H., Bao, W., Xiu, C., Zhang, Y., \& Xu, H. (2010). Energy conservation and circular economy in China's process industries. Energy, 35(11), 4273-4281. https://doi.org/10.1016/j.energy.2009.04.021

[12] Pollard, J., Osmani, M., Cole, C., Grubnic, S., \& Colwill, J. (2021). A circular economy business model innovation process for the electrical and electronic equipment sector. Journal of Cleaner Production, 305, 127211. https://doi.org/10.1016/j.jclepro.2021.127211

[13] Siegert, M. W., Saling, P., Mielke, P., Czechmann, C., Emara, Y., \& Finkbeiner, M. (2020). Cradle-to-grave life cycle assessment of an ibuprofen analgesic. Sustainable $\begin{array}{lll}\text { Chemistry and } & \text { Pharmacy, } & 100329 .\end{array}$ https://doi.org/10.1016/j.scp.2020.100329 
[14]Upadhyay, A., Laing, T., Kumar, V., \& Dora, M. (2021). Exploring barriers and drivers to the implementation of circular economy practices in the mining industry. $\begin{array}{llll}\text { Resources } & \text { Policy, } & \text { 72(February }\end{array}$ https://doi.org/10.1016/j.resourpol.2021.102037

[15] Velasquez, M. G. (2014). Business Ethics: Concepts and Cases (7th ed.). Pearson Education Limited.

[16] Business Magazine. 2020. Business News, August 25, 2020

[17] Sido Muncul. Berbudaya Lokal Bereputasi Global. Presentasi Kandidat Emas Proper 2020.

[18] PT Pembangkitan Jawa Bali (PJB)

[19]PT PKT Bontang, East Kalimantan. Mewujudkan Masyarakat Mandiri dan Berkelanjutan. Presentasi Kandidat Proper Emas. 2018 